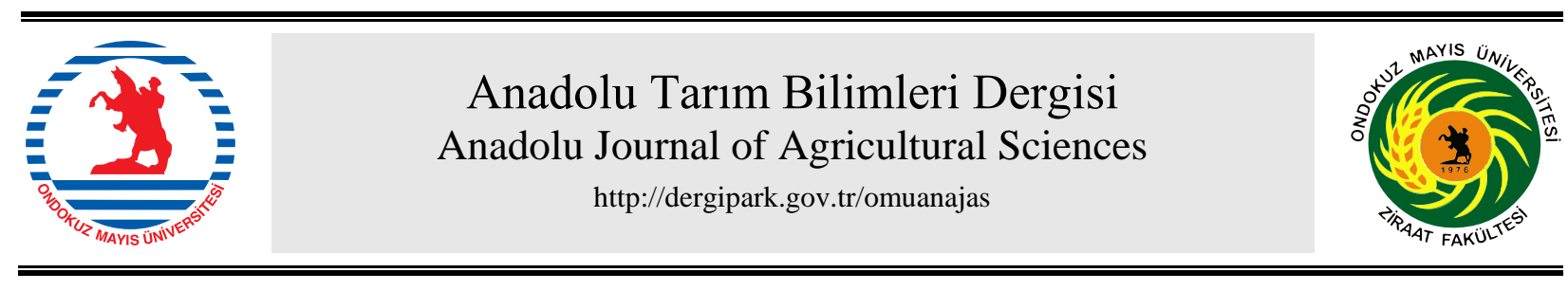

Araştırma/Research

Anadolu Tarım Bilim. Derg./Anadolu J Agr Sci, 33 (2018)

ISSN: 1308-8750 (Print) 1308-8769 (Online)

doi: 10.7161/omuanajas.311256

\title{
İki farklı olgunlaşma döneminde farklı parçalama boyutu ve sıkıştırma basıncının misır silajının kalitesi üzerine etkileri
}

\author{
Bircan Akdeniz ${ }^{\mathrm{a}}$, Cengiz Özarslan ${ }^{\mathrm{b} *}$ \\ ${ }^{a}$ Söke Zirai Üretim Isşletmesi Tarımsal Yayım ve Hizmetiçi Eğitim Merkezi Müdürlüğü, Aydın \\ ${ }^{b}$ Adnan Menderes Üniversitesi, Ziraat Fakültesi, Biyosistem Mühendisliği Bölümü, Aydın \\ "Sorumlu yazar/corresponding author: ozarslanc@yahoo.com
}

Geliş/Received 09/05/2017～Kabul/Accepted 21/01/2018

\begin{abstract}
ÖZET
$\mathrm{Bu}$ çalışma farklı olgunlaşma döneminde, farklı parçalama boyutu ve sıkıştırma basıncının mısır silajının kalitesi üzerine etkilerini belirlemek amacıyla yapılmıştır. Bu amaçla; $1 / 4$ ve 1/2 süt çizgisi olgunluk dönemlerinde tek sıralı silaj makinesi ile hasat edilen silajlık misır, hasat anında ortalama 18 ve $22 \mathrm{~mm}$ boyutlarında kıyılmıştır. Elde edilen mısır hasılı, 2 litrelik PVC tüpler içerisine, 1 ve $2 \mathrm{MPa}$ basınç değerlerinde sıkıştırılarak tam dolu halde ağızları kapatılıp fermantasyona bırakılmıştır. Doksan günlük fermantasyon sürecinden sonra mısır silajlarının fiziksel ve kimyasal analizleri yapılmış ve silaj kaliteleri belirlenmiştir. Hasat döneminin ilerlemesi ile $\mathrm{pH}$, kuru madde (KM), ham kül (HK), ham yağ (HY), nötral deterjanda çözünmeyen lif (NDF), asit deterjanda çözünmeyen lif (ADF) ve metabolik enerji (ME) değerleri KM'de \% olarak surasıyla 3.83-3.88, 31.94-33.98, 4.82-5.32, 2.94-2.43, 37.89$43.76,24.09-27.04$ ve 2.32-2.20 Mcal kg-1 olarak belirlenmiştir $(\mathrm{p}<0.01)$. Ayrıca hasat döneminin ilerlemesine bağlı olarak Flieg puanı (FP) 115.74'den 117.62 değerine yükselmiştir ( $<<0.05$ ). S1kıştırma basıncinın arttırılması, $\mathrm{pH}$, HY ve ham protein (HP) seviyelerini sirasiyla 3.84-3.87, 2.62-2.75 ve 7.607.77 değerleri arasında değiştirmiştir $(\mathrm{p}<0.01)$. Kıyma boyutunun arttırılması lignin değerini 3.28 'den 3.48 değerine yükseltmiştir $(\mathrm{p}<0.05)$. Çalışmada elde edilen silajların tümü Flieg eşitliğine göre 100 puanın üzerinde puan almış pekiyi silaj kalite sınıfında silajlardır. Çalışmaya göre $1 / 4$ veya $1 / 2$ süt çizgisinde hasat edilen mısırın, 17-20 mm boyutlarında kıyılması ve $1 \mathrm{MPa}$ basınç ile sıkıştırılmasının uygun olacağı sonucuna varılmıştır.
\end{abstract}

The effects of different chopping lengths and compressing pressures on corn silage quality at two stage of maturity

\section{ABSTRACT}

This study was conducted to determine effects of different harvesting period, chopping length and compression pressure on corn silage quality. For this purpose corn, which was at $1 / 4$ and $1 / 2$ milk line maturity period, was harvested by single row forager and chopped at 18 and $22 \mathrm{~mm}$ sizes. Harvested corn was ensiled in 2 liter PVC tubes at 1 and $2 \mathrm{MPa}$ pressure for fermentation. The physical and chemical analysis was performed after the ninety-day fermentation process and silage quality was determined. The $\mathrm{pH}$, dry matter (DM), crude ash (CA), crude fat (CF), neutral detergent fiber (NDF), acid detergent fiber (ADF) and metabolic energy (ME) values were \% 3.83-3.88, 31.94-33.98, 4.825.32, 2.94-2.43, 37.89-43.76, 24.09-27.04 and 2.32-2.20 Mcal kg-1 respectively with progressing of harvesting period $(\mathrm{p}<0.01)$. Flieg Scores were also increased from 115.74 to 117.62 depending of harvesting period $(\mathrm{p}<0.05) . \mathrm{pH}$, crude fat and crude protein level values were changed respectively (3.84-3.87), (2.62-2.75) and (7.60-7.77) with increasing of compressing pressure $(\mathrm{p}<0.01)$. Lignin was increased from 3.28 to 3.48 ( $\mathrm{p}<0.05$ ) by increasing the chopping size. The Flieg score of all silages was 100 point Flieg Score. It was concluded that corn harvested at $1 / 4$ or $1 / 2$ milk line maturity can be chopped at 17-20 mm size and can be compressed with $1 \mathrm{MPa}$ for well quality silage.
Anahtar Sözcükler:

Misir silaj1

Hasat dönemi

Kiyma boyutu

Sikıştırma basıncı

Silaj kalite sınıfı
Keywords:

Corn silage

Harvesting period

Chopping length

Compressing pressure

Silage quality

(C) OMU ANAJAS 2018 


\section{Giriş}

Süt sığırlarının beslenmesinde kullanılan en önemli kaba yem türü mısır silajıdır. Çünkü mısır silajı, birim alandan elde edilen yüksek kuru madde (KM) miktarına ve yüksek enerji değerine sahiptir. Ayrıca silolamada mekanizasyona uygun yemdir. Misır silajı nötral çözücülerde çözünmeyen lif (NDF) kaynağıdır. Dolayısıla yüksek enerji değerine sahip bir kaba yemdir (Fernandez ve ark., 2004; NRC, 2001; Keleş ve Çıbık, 2014).

Silaj üretiminde, silajın kalitesine ürünün nem içeriği, kıyma boyutu, sıkıştırma düzeyi ve silolama tekniği önemli ölçüde etki etmektedir. Yapılan çalışmalar silajı yapılacak bitkinin en az \%30-40 oranında kuru madde içermesi, yüksek kuru madde içeren bitkilerin daha küçük $(1 \mathrm{~cm})$, düşük kuru madde içeren bitkilerin ise daha büyük boyutlarda $(4 \mathrm{~cm})$ kıyılması, üründen su çıkışının minimum düzeyde kalması için sıkıştırma basıncının 2 MPa'1 geçirilmemesi ve hasattan silonun kapatılmasına kadar bütün işlemlerin düzgün ve bilinçli bir şekilde yapılması gerektiğini ortaya koymaktadır (Kılıç, 1986; Emen ve ark., 1996; Filya, 2002; Yalçın ve Çakmak, 2005).

Keleş ve Çıbık (2014), mısır silajının besleme değeri üzerine hasat zamanı, çeşit, mekanizasyon ve silaj fermantasyonunun etkilerini incelemiş ve mısır silajında bulunması gereken bazı özellikleri önermişlerdir. Çalışmada silajlık mısır hibritlerinde KM verimi ve besin değerinin optimizasyonunun danedeki süt çizgisinin 1/2-2/3 olduğu dönemde gerçekleștiği, hedef bir mısır silajının \%31-35 arasında KM içermesi, metabolik enerji (ME) değerinin kuru madde bazında 2.27 $\mathrm{Mcalkg}^{-1}$ 'den daha fazla olmasi ve 3.8-4.1 pH değerine sahip olması gerektiğini ifade etmişlerdir.

$\mathrm{Bu}$ çalışmanın amacı; farklı olgunluk dönemlerinde yapılan hasatla, farklı kıyma boyutu ve sıkıştırma basınç değerleri altında elde edilen mısır silajının fermantasyon niteliğini belirlemek, hasat dönemi, kıyma boyutu ve sıkıştırma basıncının mısır silajının yem niteliği üzerindeki etkisini ortaya koymaktır.

\section{Materyal ve Yöntem}

$\mathrm{Bu}$ çalışma, Söke Zirai Üretim İşletmesi Tarımsal Yayım ve Hizmetiçi Eğitim Merkezi Müdürlüğü'nde (Söke TAYEM) yürütülmüştür. Arazi çalışmaları TAYEM'de 2014 yılında, laboratuvar çalışmaları ise Adnan Menderes Üniversitesi Ziraat Fakültesinde 2015 yilında tamamlanmıştır. Silaj materyali olarak normal yetiştirme koşullarında üretilen ikinci ürün KWS-Doge çeşidi silajlık mısır kullanılmıştır. Silajlık mısır hasadı $70 \mathrm{~kW}$ gücünde Case III JX95 traktöre bağlanan tek sıralı disk kıyıcılı silajlık misır hasat makinası ile yapılmıştır.

Çalışmada silajlık mısır, iki farklı hasat döneminde; $1 / 4$ süt çizgisi olgunluk döneminde (1/4 SÇOD) ve $1 / 2$ süt çizgisi olgunluk döneminde
(1/2 SÇOD) tek sıralı disk kıyıcılı silajlık mısır hasat makinesi ile iki farklı kıyma boyutu elde edebilmek için 10 bıçakla kısa (K) ve 5 biçakla uzun (U) kıyma boyutlarında hasat edilmiştir. Çalışma, kıyılan materyalin 2'şer litrelik tüplere hidrolik pres ile iki farklı basınçta (1 $\mathrm{MPa}$ ve $2 \mathrm{MPa}$ ) üç tekerrürlü olarak sıkıştırılması suretiyle yürütülmüştür. Hava almayacak şekilde kapatılan silolar, daha sonra silaj analizlerini yapmak üzere fermantasyon sürecine bırakılmıştır.

Kıyma boyut analizi için hasat aşamasında kıyılmış ürün örnekleri tarım arabasından alınmış ve elek analizi yapılmıştır. Elek düzeninde toplam 6 adet eleğin yukarıdan aşağı elek delik çapına göre 80-40-20-10-5$2.5 \mathrm{~mm}$ aralıklarında eleme yapılmıştır (Bockisch ve Aumüller, 1989; Waszkiewicz ve ark., 1999).

Kıyılmış mısır silaj materyalinin doğal hacim ağırlığı $\left(\mathrm{kgm}^{-3}\right)$; standart tartım yöntemi kullanılarak belirlenmiş̧ir. $\mathrm{Bu}$ yöntem; 1 litrelik kap içerisine 150 $\mathrm{mm}$ sabit yükseklikten serbest birakılarak doldurulan silaj materyalinin tartımı ile gerçekleştirilmiştir (Suthar ve Das, 1996; Özarslan, 2002).

Aşağıdaki eşitlik kullanılarak her bir materyalin ağırlıklı ortalama çapları hesaplanmıştır (Evrenosoğlu, 2012).

$$
A O C=\frac{\sum X_{i} \cdot W_{i}}{\sum W}
$$

$A O C ̧$ : Ağırlıklı ortalama çap (mm)

$X_{i}:$ Kıyılmış materyal boyut grubu geometrik ortalama çapı $(\mathrm{mm})$

\section{$W_{i}:$ Kıyılmış materyal grubundaki hasıl miktarı (g)}

\section{$\Sigma W \quad$ : Toplam hasil miktarı $(\mathrm{g})$}

Fermantasyon sürecinin 90. gününde örnekler açılarak fiziksel ve kimyasal analizlerle silaj örneklerinin, kuru madde (KM), $\mathrm{pH}$, ham protein (HP), ham yağ (HY), ham kül (HK), acid detergent fiber (ADF), nötr detergent fiber (NDF), lignin düzeyleri ve yem nitelikleri belirlenmiştir. Mısır silajının besin değerleri ile fermantasyon özelliklerinin belirlenmesi amaciyla her bir silodan $100 \mathrm{~g}$ örnek kurutularak KM düzeyleri belirlenmiştir. Yem hammaddelerinin $\mathrm{KM}$ düzeyleri $60{ }^{\circ} \mathrm{C}$ 'de en az 48 saat süre ile etüvde kurutularak belirlenmiştir. Kurutulmuş materyal ögütüldükten sonra kimyasal analizlere tabi tutulmuştur. Yemlerin HP, HY ve HK içerikleri A.O.A.C. (1990)'ye göre; NDF ve ADF içerikleri ise Van Soest ve ark. (1991) tarafindan bildirilen yöntemlere göre ANKOM 200 Fiber Analyzer (ANKOM, USA) cihazı kullanılarak belirlenmiştir. Lignin, ADF'si yapılmış örneklerin 3 saat $\% 72$ 'lik $\mathrm{H}_{2} \mathrm{SO}_{4}$ solüsyonu ile Daisy II inkübatörde muamele edilmesi ile belirlenmiştir. Silajların pH'sı 20 g silaj numunesinin $180 \mathrm{ml}$ saf su ile 1 dakika süre ile laboratuvar tipi blenderde homojenizasyonundan elde edilen silaj süzüntüsünden belirlenmiştir. Örneklerin metabolik enerji (ME) değeri NRC (2001)'e göre 
hesaplanmıştır.

Silaj kalite sınıfinın (SKS) belirlenmesinde Alman Tarım Örgütü (DLG, 1987) tarafindan oluşturulmuş, Flieg Puanlama Yöntemi esas alınmış ve silaj kalite sınıfi bir regresyon eşitliği yardımı ile belirlenmiştir (Kılıç, 2006; Tümer, 2001).

Flieg Puanı $(\mathrm{FP})=[220+(2 \cdot$ silaj kuru maddesi $(\%)-$ 15)] - 40.silaj $\mathrm{pH}$ değeri

Eşitlikten elde edilen Flieg puanı Çizelge 1'de verilen puan kriterlerine göre, silajın kalitesi hakkında önemli ipuçları vermektedir (Nauman ve Bassler, 1993; Yildız, 2008).

Çizelge 1. Silo yemlerinin Flieg puanına göre kalite sinifları

\begin{tabular}{ll}
\hline Flieg Puanı (FP) & Silaj Kalite Sınıfi (SKS) \\
\hline $81-100$ & I - Pekiyi \\
$61-80$ & II - İyi \\
$41-60$ & III - Orta \\
$21-40$ & IV - Düşük \\
$0-20$ & V - Kötü \\
\hline
\end{tabular}

Flieg puanlama sistemine göre yapılan fiziksel değerlendirme ve silaj örneklerinin kimyasal analizlerinden elde edilen veriler, varyans analizine tabi tutulmuştur. Grup ortalamalarının çoklu karşılaştırılması Duncan testi ile yapılmıştır (Yıldız ve Bircan, 1994). Verilerin istatistik analizinde SPSS (Versiyon 15) paket programı kullanılmıştır.

\section{Bulgular ve Tartışma}

İki farklı kıyma boyutunda $1 / 4$ SÇOD ve $1 / 2$ SÇOD'de hasat edilen silajlık misır materyalinin silolama öncesi KM oranı ile elek analizi sonucu belirlenen parça boyut dağılımı ve ağırlıklı ortalama çap (AOÇ) değerleri Çizelge 2'de görülmektedir.

Farklı hasat dönemi, farklı kıyma boyu ve sıkıştırma basıncının silo hacim ağırlığı üzerine etkileri incelendiğinde; hasat döneminin gecikmesi ve parça boyutunun uzamasına bağlı olarak silo hacim ağırlığının azaldığı, sıkıştırma basıncının artması ile de silo hacim ağırlığının arttığı tespit edilmiştir (Çizelge 3).

Çalışmada silaj örneklerinin $\mathrm{pH}$ ve $\mathrm{KM}$ oranlarına bağlı olarak FP ve SKS'ları belirlenmiştir (Çizelge 4). Tüm örnekler için genel ortalama FP 116.68 olarak tespit edilmiştir. Bu değer Çizelge 1'de verilen SKS gruplarına göre, I. sınıf ve pekiyi nitelikte silajı ifade etmektedir.

FP üzerinde hasat döneminin istatistiksel olarak etkisinin olduğu saptanmıştır $(\mathrm{p}<0.05)$. Tüm silajların FP'ları Yıldız ve ark. (2011) ve Çakmak ve ark. (2013)'nin çalışmalarında ortaya konan FP'ları ile uyumludur. Çalışmaya göre kıyma boyutu ve sıkıştırma basıncı FP'nı etkilememiştir. Bu nedenle daha az enerji gerektiren U kıyma boyutu ve $1 \mathrm{MPa}$ sıkıştırma basıncının tercih edilebileceği söylenebilir.

Silaj kalitesinin belirlenmesinde kullanılan en önemli kriterlerden birisi de KM içeriğidir. Kılıç (1986) kaliteli bir silo yeminin KM'sinin \%25-32 arasında, Keleş ve Çıbık (2014) kaliteli bir misır silajında hedeflenen KM'nin \%31-35 arasında olması gerektiğini ifade etmektedir. Bu çalışmada farklı koşullarda elde edilen tüm silajlar istenilen KM içeriklerine sahip olmuştur (Çizelge 5). Hasat zamanının gecikmesine bağlı olarak KM (\%31.94 - 33.98) değerinde olan artış çok önemli bulunmuştur $\quad(p<0.01)$. Misır silajında hasat zamanındaki ilerlemenin KM miktarını artırdığı araştırmacılar tarafindan belirtilmiştir (Mc Donald, 1981; Johnson ve ark., 2002; Özdüven ve ark., 2009).

Çizelge 2. Silaj materyalinin silolama öncesi fiziksel özellikleri

\begin{tabular}{|c|c|c|c|c|}
\hline \multirow{3}{*}{$\begin{array}{l}\text { Elek Aralığ } 1 \\
(\mathrm{~mm})\end{array}$} & \multicolumn{4}{|c|}{ Dağılım (\%) } \\
\hline & \multicolumn{2}{|c|}{ 1/4 SÇOD'de } & \multicolumn{2}{|c|}{ 1/2 SÇOD'de } \\
\hline & $\mathrm{U}$ & $\mathrm{K}$ & $\mathrm{U}$ & $\mathrm{K}$ \\
\hline$>80$ & 0.53 & 0.32 & 2.17 & 1.05 \\
\hline $40-80$ & 5.49 & 2.66 & 6.64 & 6.57 \\
\hline $20-40$ & 31.50 & 21.54 & 34.26 & 23.68 \\
\hline $10-20$ & 51.90 & 55.74 & 45.54 & 49.54 \\
\hline $0-10$ & 10.58 & 19.74 & 11.39 & 19.16 \\
\hline $\mathrm{AOÇ} \mathrm{(mm)}$ & 20.68 & 17.23 & 23.07 & 19.93 \\
\hline Kuru Madde (\%) & $31.33 \pm 0.44$ & $30.33 \pm 0.44$ & $37.00 \pm 0.67$ & $35.67 \pm 0.89$ \\
\hline
\end{tabular}

Çizelge 3. Silolanan silaj materyalinin hacim ağırlıkları $\left(\mathrm{kg} \mathrm{m}^{-3}\right)$

\begin{tabular}{ccccc}
\hline \multirow{2}{*}{$\begin{array}{c}\text { Silolama Basinc1 } \\
(\mathrm{MPa})\end{array}$} & $\mathrm{U}$ & $\mathrm{K}$ & $\mathrm{U}$ & \multicolumn{2}{c}{$1 / 2$ SÇOD } \\
\cline { 2 - 5 } & $856.33 \pm 27.78$ & $901.00 \pm 14.33$ & $762.25 \pm 24.25$ & $\mathrm{~K}$ \\
\hline 1 & $928.83 \pm 5.78$ & $948.00 \pm 6.00$ & $882.67 \pm 9.56$ & $891.67 \pm 11.44$ \\
\hline
\end{tabular}


Çizelge 4. Silaj örneklerinin FP'ları, standart sapma değerleri ve silaj kalite sinıfları

\begin{tabular}{lcc}
\hline Hasat Dönemi & FP & SKS \\
\hline $1 / 4$ SÇOD & $115.74 \pm 1.78 b$ & PEKIYYI \\
$1 / 2$ SÇOD & $117.62 \pm 1.57 \mathrm{a}$ & PEKIYYI \\
\hline Sıkıştırma Basıncı & & \\
\hline $1 \mathrm{MPa}$ & $116.57 \pm 1.81$ & PEKIYİ \\
$2 \mathrm{MPa}$ & $116.79 \pm 2.06$ & PEKIYİ \\
\hline Kıyma Boyu & & \\
\hline $\mathrm{K}$ & $116.91 \pm 2.09$ & PEKIYİ \\
$\mathrm{U}$ & $116.45 \pm 1.76$ & PEKIYİ \\
\hline$p$ değerleri & & \\
\hline Hasat Dönemi (HD) & $0.019 *$ & \\
Sıkıştırma Basıncı (SB) & 0.760 & \\
Kıyma Boyu (KB) & 0.526 & \\
HD x SB & 0.125 & \\
HD x KB & 0.839 & \\
SB x KB & 0.544 & \\
HD x SB x KB & 0.516 & \\
\hline Aynı sütunda farklı harfler ile gösterilen ortalamalar arasındaki \\
farklar önemlidir $(*$ p $<0.05)$ & &
\end{tabular}

Silajın fermantasyon düzeyinin önemli göstergelerinden olan $\mathrm{pH}$ değeri, pekiyi kalite sınıfında bir silajda 3.5 ile 4.3 arasında olmaktadır (Kılıç 2006, Açıkgöz ve ark., 2002; Roth, 2001). Bu çalışmada elde edilen $\mathrm{pH}$ değerlerine bakıldığında, farklı koşullar altında elde edilen silajların hepsi pekiyi kalite silaj sınıfına girmektedir (Çizelge 5). Hasat dönemi ve uygulanan basınç $\mathrm{pH}$ değerini etkilemiştir $(\mathrm{p}<0.01)$. Kıyma boyutunun ise $\mathrm{pH}$ değerine etkisi bulunmamıştır. $\mathrm{pH}$ değişiminde HDxKB interaksiyonu $(\mathrm{p}<0.05)$ önemli, diğer interaksiyonlar önemsiz bulunmuştur. Savoie ve ark. (2002) yaptıkları çalışmada mısır silajlarının pH değerlerini 3.9-4.1 arasında bulmuşlardır. Yıldız ve ark. (2011) çalışmalarında siloladıkları mısır silaj örneklerinin $\mathrm{pH}$ değerlerini 3.61-3.94 arasında bulmuşlardır. Bu çalışmada bulunan $\mathrm{pH}$ değerleri 3.833.88 değerleri arasındadır ve yukarıdaki çalışmalarla uyumludur.

Organik madde $(\mathrm{OM})$ oranı yüksek olan yemlerde HK oranı nispeten düşük olmaktadır. Hayvan beslenmesinde önemli olduğundan yemlerde OM oranının yüksek olması arzu edilmektedir. Yani yemin HK oranının düşük olması istenen bir durumdur (Çakmak ve ark., 2013).

Çizelge 5. Silolardan alınan fermente mısır silajlarının KM, pH, HK, HY ve HP değerleri $\left(\bar{X} \pm S_{\bar{X}}\right)$

\begin{tabular}{|c|c|c|c|c|c|}
\hline Hasat Dönemi & $\begin{array}{l}\mathrm{KM} \\
(\%)\end{array}$ & $\mathrm{pH}$ & $\begin{array}{l}\text { HK } \\
(\%)\end{array}$ & $\begin{array}{l}\text { HY } \\
(\%)\end{array}$ & $\begin{array}{l}\text { HP } \\
(\%)\end{array}$ \\
\hline 1/4 SÇOD & $31.94 \pm 0.77 \mathrm{~b}$ & $3.83 \pm 0.02 b$ & $4.82 \pm 0.22 b$ & $2.94 \pm 0.11 \mathrm{a}$ & $7.68 \pm 0.27$ \\
\hline 1/2 SÇOD & $33.98 \pm 0.99 a$ & $3.88 \pm 0.03 \mathrm{a}$ & $5.32 \pm 027 \mathrm{a}$ & $2.43 \pm 0.13 b$ & $7.69 \pm 0.12$ \\
\hline \multicolumn{6}{|l|}{ Sikıştırma Basıncı } \\
\hline $1 \mathrm{MPa}$ & $32.65 \pm 1.28$ & $3.84 \pm 0.04 b$ & $5.05 \pm 0.36$ & $2.62 \pm 0.32 \mathrm{~b}$ & $7.60 \pm 0.19 b$ \\
\hline $2 \mathrm{MPa}$ & $33.26 \pm 1.42$ & $3.87 \pm 0.03 \mathrm{a}$ & $5.08 \pm 0.36$ & $2.75 \pm 0.24 \mathrm{a}$ & $7.77 \pm 0.19 \mathrm{a}$ \\
\hline \multicolumn{6}{|l|}{ Kıута Воуи } \\
\hline $\mathrm{K}$ & $33.19 \pm 1.50$ & $3.86 \pm 0.04$ & $4.98 \pm 0.26$ & $2.66 \pm 0.27$ & $7.63 \pm 0.21$ \\
\hline $\mathrm{U}$ & $32.72 \pm 1.22$ & $3.85 \pm 0.03$ & $5.15 \pm 0.41$ & $2.71 \pm 0.31$ & $7.74 \pm 0.19$ \\
\hline \multicolumn{6}{|l|}{$p$ değerleri } \\
\hline Hasat Dönemi (HD) & $0.000 * *$ & $0.000^{* *}$ & $0.000 * *$ & $0.000^{* *}$ & 0.936 \\
\hline $\begin{array}{l}\text { Sikıştırma } \\
\text { (SB) }\end{array}$ & 0.093 & $0.009^{* *}$ & 0.730 & $0.001 * *$ & $0.006^{* *}$ \\
\hline Kıуma Bоуu (KB) & 0.192 & 0.183 & 0.124 & 0.124 & 0.052 \\
\hline $\mathrm{HD} \times \mathrm{SB}$ & 0.179 & 0.559 & 0.747 & $0.026^{*}$ & 0.073 \\
\hline $\mathrm{HD} \times \mathrm{KB}$ & 0.216 & $0.044 *$ & 0.703 & 0.121 & $0.001 * *$ \\
\hline $\mathrm{SB} \times \mathrm{KB}$ & 0.825 & 0.092 & 0.708 & 0.068 & 0.729 \\
\hline $\mathrm{HD} \times \mathrm{SB} \times \mathrm{KB}$ & 0.835 & 0.335 & 0.985 & 0.565 & 0.414 \\
\hline
\end{tabular}

Aynı sütunda farklı harfler ile gösterilen ortalamalar arasındaki farklar önemlidir $\left(* ; \mathrm{p}<0.05,{ }^{* *} ; \mathrm{p}<0.01\right)$. 
$\mathrm{Bu}$ çalışmada KM'deki HK oranının, hasat dönemine bağlı olarak değiştiği $(p<0.01)$, sıkıştırma basıncinın ve kiyma boyunun ise HK oranını etkilemediği saptanmıştır (Çizelge 5). Tüm silaj örneklerinde HK oranı ortalaması \%5.07 olarak bulunmuş ve değerler Çakmak ve ark. (2013)'nin bulduğu değerlerle uyumludur.

Keleş ve Çıbık (2014), ham yağın yüksek değerlerde olmasının silajın iyi bir besleme değerine sahip olduğunu ifade etmişlerdir. Bu çalışmada KM'deki HY oranının, hasat dönemi $(p<0.01)$ ve sıkıştırma basıncına $(\mathrm{p}<0.01)$ bağlı olarak değiştiği, kıyma boyutunun ise HY oranı üzerine etkisinin olmadı $\breve{g} 1$ belirlenmiștir (Çizelge 5). En yüksek değer 1/4 SÇOD (\%2.94) silajında elde edilmiş, hasadın gecikmesine (1/2 SÇOD) bağlı olarak HY oranında azalma (\%2.43) gözlenmiştir. Hasat dönemi x sıkıştırma basıncı interaksiyonu önemli bulunmuştur $(\mathrm{p}<0.05)$. Çalışmada farklı koşullardaki tüm silaj örneklerinin HY değerleri (\%2.43-2.94) Çakmak ve ark. (2013)'nin bulduğu değerlerle (\%2.142.95) uyumludur.

Farklı koşullar altında silolanan tüm mısır silajları için ortalama ham protein değeri \%7.69 olarak bulunmuştur (Çizelge 5). Sıkıştırma basıncının artması HP değerini arttırmış $(\mathrm{p}<0.01)$ ancak hasat dönemi ve kıyma boyunun HP üzerine etkisi önemsiz bulunmuştur. Hasat dönemi $x$ kıyma boyu interaksiyonu $(p<0.01)$ çok önemli, diğer interaksiyonlar ise önemsiz bulunmuştur. $\mathrm{Bu}$ çalışmada farklı koşullarda elde edilen silaj örneklerinin HP (\%7.60-7.77) değerleri, Çakmak ve ark. (2013)'nin bulduğu HP (\%7.43-8.04) değerleri ve Konca ve ark. (2005)'nin misır silajlarında buldukları HP (\%4.97-10.43) değerleri ile uyumludur.

Çeşit, kıyma uzunluğu ve mekaniksel işleme gibi faktörler, mısır silajının içerdiği NDF oranını büyük oranda etkilemektedir (Mertens, 1997; Kung ve ark., 2008; Ferraretto ve Shaver, 2012). Bu çalışmada hasat döneminin ilerlemesine bağlı olarak NDF oranının $\operatorname{arttığg~}(p<0.01)$ gözlemlenmiştir (Çizelge 6).

Her üç koşulda tespit edilen NDF değerleri hasat döneminin ilerlemesi, basınç artışı ve kıyma boyutunun azalmasına bağlı olarak NDF değerlerinin arttığını ortaya koyan Yildız ve ark. (2011)'nin değerleri ve Keleş ve Çıbık (2014)'ın bildirdiği değerler ile uyumludur.

Çizelge 6. Fermente Mısır Silajlarının KM'deki NDF, ADF, Lignin ve ME Değerleri $\left(\bar{X} \pm S_{\bar{X}}\right)$

\begin{tabular}{|c|c|c|c|c|}
\hline & $\begin{array}{l}\text { NDF } \\
(\%)\end{array}$ & $\begin{array}{l}\mathrm{ADF} \\
(\%)\end{array}$ & $\begin{array}{c}\text { Lignin } \\
(\%)\end{array}$ & $\begin{array}{c}\mathrm{ME} \\
\left(\mathrm{Mcalkg}^{-1}\right)\end{array}$ \\
\hline \multicolumn{5}{|l|}{ Hasat Dönemi } \\
\hline 1/4 SÇOD & $37.89 \pm 1.25 \mathrm{~b}$ & $24.09 \pm 1.00 \mathrm{~b}$ & $3.36 \pm 0.23$ & $2.32 \pm 0.03 \mathrm{a}$ \\
\hline 1/2 SÇOD & $43.76 \pm 1.60 \mathrm{a}$ & $27.04 \pm 1.41 \mathrm{a}$ & $3.39 \pm 0.28$ & $2.20 \pm 0.05 b$ \\
\hline \multicolumn{5}{|l|}{ Sikıştırma Basıncı } \\
\hline $1 \mathrm{MPa}$ & $40.48 \pm 3.78$ & $25.43 \pm 2.44$ & $3.39 \pm 0.29$ & $2.26 \pm 0.09$ \\
\hline $2 \mathrm{MPa}$ & $41.17 \pm 2.88$ & $25.69 \pm 1.33$ & $3.36 \pm 0.22$ & $2.26 \pm 0.06$ \\
\hline \multicolumn{5}{|l|}{ Kıута Bоyи } \\
\hline K & $41.07 \pm 3.13$ & $25.43 \pm 1.77$ & $3.28 \pm 0.26 \mathrm{a}$ & $2.27 \pm 0.07$ \\
\hline $\mathrm{U}$ & $40.58 \pm 3.60$ & $25.70 \pm 2.14$ & $3.48 \pm 0.22 b$ & $2.26 \pm 0.08$ \\
\hline \multicolumn{5}{|l|}{$p$ değerleri } \\
\hline Hasat Dönemi (HD) & $0.000 * *$ & $0.000 * *$ & 0.654 & $0.000 * *$ \\
\hline Sıkıştırma Basıncı(SB) & 0.264 & 0.625 & 0.787 & 0.977 \\
\hline Kıyma Boyu (KB) & 0.421 & 0.601 & $0.026^{*}$ & 0.542 \\
\hline $\mathrm{HD} \times \mathrm{SB}$ & 0.264 & 0.075 & $0.003 * *$ & $0.040^{*}$ \\
\hline $\mathrm{HD} \times \mathrm{KB}$ & 0.548 & 0.334 & 0.400 & 0.339 \\
\hline $\mathrm{SB} \times \mathrm{KB}$ & 0.445 & 0.583 & 0.575 & 0.609 \\
\hline $\mathrm{HD} \times \mathrm{SB} \times \mathrm{KB}$ & 0.412 & 0.980 & 0.184 & 0.401 \\
\hline
\end{tabular}

Aynı sütunda farklı harfler ile gösterilen ortalamalar arasındaki farklar önemlidir (*; $\left.<<0.05,{ }^{* *} ; \mathrm{p}<0.01\right)$. 
Çalışmada hasat döneminin ilerlemesine bağlı olarak ADF (\%24.09-\%27.04) değerinin artı̧̧1 çok önemli $(\mathrm{p}<0.01)$ bulunmuş, sıkıştırma basıncının ve kıyma boyutunun ADF değerine etkisinin olmadığı, ikili ve üçlü interaksiyonların da önemsiz olduğu tespit edilmiştir (Çizelge 6). Çalışmada bulunan ADF değerleri, Keleş ve Çıbık (2014)'in derleme çalışmasında belirttiği hedef değerleri içeren ADF (\%22-28) değerleri ile uyumludur.

Çalışmada hasat kıyma boyunun lignin (\%3.28-3.48) değerleri üzerine etkisi önemli $(\mathrm{p}<0.05)$, hasat dönemi ve sıkıştırma basıncının etkisi ise önemsiz bulunmuştur (Çizelge 6). HD x SB interaksiyonu çok önemli $(\mathrm{p}<0.01)$ bulunurken, HD x KB, SB x KB ve HD x SB x $\mathrm{KB}$ interaksiyonları önemsiz bulunmuştur. Lignin değerleri Keleş ve Çıbık (2014)'ın çalışmasında bildirdiği lignin (\%1.8-3.5) değerleri ile uyumludur.

Kaliteli silajda ME değerinin kuru madde bazında $1.91 \mathrm{Mcalkg}^{-1}$ 'in üzerinde olması istenmektedir (Brade ve Flachowsky, 2007). Bu çalışmada elde edilen tüm silajların ME değerlerinin bu değerden daha yüksek olduğu (2.20-2.32 $\mathrm{Mcalkg}^{-1}$ ) görülmektedir (Çizelge 6).

Bu sonuçlar Alçiçek ve ark. (1999)'in elde ettikleri 2.20 ile $2.57 \mathrm{Mcal} \mathrm{kg}^{-1}$ değerleri ile de örtüşmektedir. Silajların ME değerleri; hasat dönemine göre değişmektedir $(\mathrm{p}<0.01)$. Sikıştırma basıncı ve kıyma boyutunun ME üzerinde etkisi önemli bulunmamıştır.

\section{Sonuç}

Çalışmada gerçekleştirilen kimyasal analiz sonuçları, elde edilen tüm silaj örneklerinin kaliteli bir yem olduğunu göstermektedir. Üretilen silajlar Flieg Puanlama Sistemine göre pekiyi kalite sınıfındadır. Farklı koşullara rağmen tüm silajların kaliteli olmasında, uygun KM oranı, sıkıştırma basıncı ve kıyma boyutu ile birlikte ürün olarak misırın kullanılmasının da büyük etkisi olmuştur. Çünkü silaj yapımı için mısır mükemmel bitki olarak tanımlanmaktadır (Fernandez ve ark., 2004; NRC, 2001).

Misır bitkisi $1 / 4$ veya $1 / 2$ süt çizgisi olgunluk dönemlerinde (\%31-36 KM) hasat edilerek içerisine hiçbir katk1 maddesi ilave etmeden, kaliteli ve yem niteliği yüksek mısır silajı yapılabilir.

Silajlı mısır bitkisinin silolama öncesi farklı boyutlarda parçalanması silaj kalitesini etkilememektedir. Bununla beraber misirın 17-20 mm AOÇ'larında kıyılması, silolama kapasitesini artırması ve daha etkin parçalanmanın sağlanması ile lignin değerini düşürmesi bakımından daha uzun parçalama boyutlarına tercih edilmelidir.

Parçalanmış silajlık mısır materyalinin silolanması sırasında uygulanan $1 \mathrm{MPa}$ ve $2 \mathrm{MPa}$ sıkıştırma basınçlarında kaliteli silajlar elde edilmektedir. Yüksek basınçlarda sıkıştırma, özellikle düşük KM içerikli mısır silaj materyallerinde silo suyu çıkışı nedeniyle besin kaybına yol açacağından arzu edilmemektedir. $\mathrm{Bu}$ açıdan silolama sırasında $1 \mathrm{MPa}$ sıkıştırma basıncı kaliteli bir silaj elde etmek için yeterli olacaktır, bununla beraber yüksek sıkıştırma basıncı ile birim alana daha fazla silajın depolanabileceği de göz önünde bulundurulmalıdır. Ancak daha az enerji ile daha düşük sıkıştırma basınçlarında da kaliteli silajın elde edilebilirliği konusuna yönelik çalışmaların yapılması gerektiği düşünülmektedir.

\section{Teşekkür}

Bu çalışma Adnan Menderes Üniversitesi Bilimsel Araştırma Projeleri tarafından desteklenen yüksek lisans tezinin bir bölümünü içermektedir (Proje Numarası: ZRF-15033). Katkılarından dolayı Adnan Menderes Üniversitesi Bilimsel Araştırma Projeleri Birimine teşekkür ederiz.

\section{Kaynaklar}

Açıkgöz, E., Turgut, İ., Filya, İ., 2002. Silaj bitkileri yetiştirme ve silaj yapımı, Hasat Yayınları, İstanbul

Alçiçek, A., Tarhan, F., Özkan, K., Adışen, F. 1999. İzmir ili ve civarında bazı süt sığırcılığı işletmelerinde yapılan silo yemlerinin besin madde içeriği ve silaj kalitesinin saptanması üzerine bir araştırma. Hayvansal Üretim, 39-40: 54-63

A.O.A.C., 1990. Official methods of analysis of the association of official analytical chemists. 15 th Edn. Vol. 1, Washington, D.C

Bockisch, F., Aumüller. C., 1989. Anforderungen an die hackselqualitat, Landtechnik, 4/89, 3s

Brade, W., Flachowsky, G., 2007. Rinderzucht und rindfleischerzeugung _ $\quad-\quad$ landbauforschung völkenrode, sonderheft 313 / Special Issue FAL Agricultural Research

Çakmak, B., Yalçın, H., Bilgen, H., 2013. Hasıl ve fermente mısır silajlarının ham besin maddesi içeriğ ve kalitesine paketleme basinci ve depolama süresinin etkileri, Ankara Üniversitesi, Tarım Bilimleri Dergisi, 19 (2013) 22-33 DLG, 1987.

DLG -Pattern for the evulation of the fermentation quality of grass silages on the basis of chemical analyses. Frankfurt am Main: Deutsche Landwirtschafts Gesellschaft. Bewertungvon Grünfutter, Silageund Heu. Merkblatt, No.224 DLG Verlag, Frankfurt

Emen, K., Pekcan, İ., Yaşar, H., Asma, S., 1996. Silaj yapım tekniği ve silaj makinaları. T.C. Tarım ve Köyişleri Bakanlığı, Tarım Alet ve Makinaları Test Merkezi Müdürlüğ̈̈, Yayın No:5, 60 s, Ankara

Evrenosoğlu, M., 2012. Mısır silaj yemi yapımında kullanılan mekanizasyon yöntemlerinin farklı silolama tekniklerine göre incelenmesi, E.Ü. Ziraat Fakültesi, Tarım Makinaları Ana Bilim Dalı, Doktora Tezi, İzmir

Fernandez, I., Martin, C., Champion, M., MichaletDoreau, B., 2004. Effect of corn hybrid and chop 
length of whole-plant corn silage on digestion and intake by dairy cows. J. Dairy Sci., 87: 1298-1309

Ferraretto, L.F., Shaver, R.D., 2012. Meta-analysis: effect of corn silage harvest practices on intake, digestion, and milk production by dairy cows. The Professional Animal Scientist, 28: 141-149

Filya, İ., 2002. Silaj yapımı. Silaj bitkileri yetiştirme ve silaj yapımı. Hasad Yayıncılık, Kayseri, 59-86

Johnson, L.M., Harrsion, J.H., Davidson, D., Mahanna, W.C., Shinners,K., Linder, D. 2002. Corn silage management: effects of maturity, inoculation and mechanical processing on packdensity and aerobic stability. J. Dairy Sci., 85: 434-444

Keleş, G., Çıbık, M., 2014. Mısır silajının besin ve besleme değerini etkileyen faktörler. Adnan Menderes Üniversitesi, Ziraat Fakültesi, Zootekni Bölümü, Yemler ve Hayvan Besleme Anabilim Dalı. Hayvansal Üretim Dergisi, 55(2): 27-37, Aydın

Kılıç, A., 1986. Silo yemi (Öğretim, Öğrenim ve Uygulama Önerileri). Bilgehan Basımevi, $327 \mathrm{~s}$, İzmir

Kılıç, A., 2006. Kaba yemlerde niteliğin saptanması. Hasat Yayıncılık, İstanbul

Konca, Y., Alçiçek, A., Yaylak, E., 2005. Süt sığırcıllı̆g işletmelerinde yapılan silo yemlerinde silaj kalitesinin saptanması. Ege Üniversitesi Ziraat Fakültesi Zootekni Bölümü Hayvansal Üretim Dergisi, 46(2): 6-13, İzmir

Kung, L., Moulder, B.M., Mulrooney, C.M., Teller, R.S., Schmidt, R.J., 2008. The effect of silage cutting height on the nutritive value of a normal corn silage hybrid compared with brown midrib corn silage fed to lactating cows. J. Dairy Sci., 91: 14511457

Mc Donald, P., 1981. The biochemistry of silage. J.W. Publ. Manchester

Mertens, D.R., 1997. Creating a system for meeting the fiber requirements of dairy cow. J. Dairy Sci., 80: 1463-1481

Nauman, C., Bassler, R., 1993. Die chemische untersuchung von futtermittein. methodenbuch, Band III. VDLUFA-Verlag, Darmstadt

NRC, 2001. National research council. nutrients requirements of dairy cattle. The National Academic Press. Washington DC., USA
Özarslan, C., 2002. Physical properties of cotton seed. Biosystems Engineering, 83(2):169-174

Özdüven M.L., Koç F., Polat C., Coşkuntuna L., Başkavak S., Şamlı H.E., 2009. Bazı mısır çeşitlerinde vejetasyon döneminin silolamada fermantasyon özellikleri ve yem değeri üzerine etkileri. Tekirdağ Ziraat Fakültesi Dergisi, 6(2):121129

Roth, G.W., 2001. Corn silage productionand management. College of Agricultural Sciences. Agricultural Research and Coop. Extension, Agronomy Facts, 18

Savoie, P. Amyot, A., Theriault, R., 2002. Effect of moisture content, chopping and processing on silage effluent. Transactions of the ASAE, 45(4): 907-914

Suthar, S. H., Das, S. K. 1996. Some physical properties of karingda (Citrulluslanatus) seeds. Journal of Agricultural Engineering Research, 65(1), 15-22

Tümer, S., 2001. Silaj, T.C. Tarım ve Köyişleri Bakanlığı, Ege Tarımsal Araştırma Enstitüsü Müdürlüğ̈̈, Yayın No: 104, İzmir

Van Soest, P.J., Robertson, B.J., Lewis, B.A., 1991. Methods for dietary fiber, neutral detergent fiber and non-starch polysaccharides in relation to animal nutrition. J. DairyScience, 74:3583-3597

Waszkiewicz, Cz., Gach, S. Lisowski, A., Kostyra, K., 1999. Effect of size reduction degree on the quality of hay silage, Department of Farm Machinery, Warsaw Agricultural University, Poland, pages:3

Yalçın, H., Çakmak, B., 2005. Bazı kaba yemlerin sıkıştırılabilirlik özellikleri. Ege Üniversitesi Bilimsel Araştırma Projesi Kesin Raporu, Proje No:01-ZRF-42, İzmir

Yıldız, N., Bircan, H., 1994. Araştırma ve deneme metotları, Atatürk Üniversitesi Yayınları No:697, Erzurum

Yıldız, C., 2008. Farklı koşullarda paketlenmiş mısır küçük balya silajı yapımı için uygun parametrelerin belirlenmesi, Atatürk Üniversitesi Fen Bilimleri Enstitüsü, Tarım Makinaları Anabilimdalı, Doktora Tezi, Erzurum

Yıldız, C., Öztürk, İ., Erkmen, Y., 2011. Farklı hasat dönemi, kıyma boyutu ve sıkıştırma basıncının mısır silajının fermantasyon niteliği üzerine etkileri. Iğdır Üniv. Fen Bilimleri Enst. Dergisi, 1(2): 85-90 